\title{
THE EFFECT OF VILLAGE DEVICE COMPETENCIES AND INTERNAL CONTROL SYSTEM ON ACCOUNTABILITY OF VILLAGE MANAGEMENT
}

\author{
Dian Astri Budiana \\ Magister of Regional Financial, Graduate School of Economics \\ Hasanuddin University, Makassar \\ South Sulawesi, Indonesia \\ Darwis Said \\ Ph.D of Economics, Graduate School of Economics \\ Hasanuddin University, Makassar \\ South Sulawesi, Indonesia \\ Nursini \\ Ph.D of Economics, Graduate School of Economics \\ Hasanuddin University, Makassar \\ South Sulawesi, Indonesia \\ DOI: 10.31364/SCIRJ/v7.i1.2019.P0119599 \\ http://dx.doi.org/10.31364/SCIRJ/v7.i1.2019.P0119599
}

\begin{abstract}
This study aims to determine the effect of village competency and internal control systems on the accountability of village fund management in three sub-districts in Enrekang Regency.

The data used in this study are primary data using a questionnaire. The population in this study were village officials involved in managing village finance at each village government. For respondents in each village there were 3 village financial management officials (village head, village secretary, treasurer) and 3 community leaders. The sample of this study was 145 samples. The research method used in this study is a multiple linear regression method using SPSS version 22 software.

The results of the study showed that the influence of village competency had a positive and significant effect on the accountability of village fund management with an effect value of 0.288 . While the internal control system has a positive and significant effect on the accountability of village fund management with an influence value of 0.328 .
\end{abstract}

Keywords: competence, internal control system, accountability, Enrekang

\section{INTRODUCTION}

The village governance policy contained in Law Number 6 of 2014 concerning Villages is considered a policy that brings new hope in efforts to improve the welfare of rural communities. Some of these policies, including large budget allocations to villages, are intended to increase village budgets in the development, service, development and empowerment of rural communities. Then there is the provision of fixed income and benefits to the village head along with the equipment which is expected to improve service to all village communities.

Fiscal decentralization into this village will provide a larger budget to villages in using the budget they have according to policies taken to provide services, development, and empowerment of rural communities. The Village Law also provides a more certain guarantee that each village will receive funding from the government through the state and regional budgets which are multiplied in number, far above the amount currently available in the village budget.

Village funds in their management are carried out in an orderly manner, obeying the provisions of laws and regulations, efficient, economical, effective, transparent and responsible by paying attention to the sense of justice and propriety and prioritizing the interests of the local community, listed in Government Regulation 22 of 2015 concerning Village Funds . The allocation of village funds is calculated based on the number of villages and by taking into account the population, poverty rate, area size, and level of geographical difficulties. Village funds are transferred through the district / city APBD and then transferred to the Village Budget. Management of village funds in the district / city APBD in accordance with the provisions of legislation in the area of regional 
management. Village fund management in the Village Budget is carried out according to the provisions of legislation in the field of village financial management.

Village is the lowest unit in the government system in Indonesia. Its role, function and contribution occupy a strategic position. The reason for the village is an important unit that must get attention from the State and the state bureaucracy because of the consideration that our people mostly live in the village and there are many problems that can only be overcome from rural units. So if you want to find the right size in assessing whether a nation is prosperous or not, fair or not, dignified or not, then the village is the most relevant unit to learn (Wahyuddin, 2016).

The village budget is Rp. 46.9 Trillion which will be disbursed by the central government as an implication of the birth of the Law on Villages is considered prone to corruption and can drag the next village head to prison. With the varied characteristics of the village, the competency of village officials and relatively new regulations, it is estimated that there is a considerable amount of potential fraud in each stage of village fund management, from the planning process to the monitoring and evaluation stages. Based on the findings of the NGO Indonesian Paralegal Network (JPI), some of the corruption cases at the village level were not because of the village head's criminal intentions. But because of the lack of understanding of the village heads in utilizing the budget (Setiana, 2017).

There is a demand for accountability and transparency in recording transactions, and reporting on government performance by interested parties to make government accounting a necessity that is no longer inevitable today. Government accounting has a role in managing public finance in realizing good governance, starting from central, regional and village financial governance.

Principles in government accounting such as accountability and transparency, management of public finances are not only a form of obligation from the central government, but also in areas such as villages. The village as a unit of government organization dealing directly with the community with all backgrounds of interests and needs has a role that is very much determined by the progress of the village, because there is no developed country without an advanced province, there is no developed province without developed villages. This means that the basis of a country's progress is determined by the progress of the village.

Accountability is the obligation to deliver accountability or to answer and explain the performance of one's actions / legal entity / collective leadership of an organization to those who have the right or authority to ask for information or accountability. The increasing public demand for good governance has encouraged the central government and regional governments to implement public accountability. As a form of obligation to account for the success or failure of the organization's mission in achieving its stated goals and objectives, village development has a very vital role in increasing national development and regional development because the village has the authority, duty, and obligation to regulate and manage household interests ( the community) themselves.

Effective accountability will be realized if the information delivered is easy to understand. The community as a party that gives trust to the government to manage public finance has the right to obtain government financial information to evaluate the government (Mardiasmo, 2009). The community not only has the right to know financial management but also has the right to demand accountability for the application and implementation of the financial management of the area, because government activities are in order to carry out the people's mandate (Halim, 2007).

In the management of village funds required to apply the principle of accountability, in order to achieve all the plans that have been prepared in managing village funds, with good accountability from the village government there will be good governance and can improve the quality of services to the community so that village funds can have a big impact on community development.

Many factors influence the accountability of village funds. In this study there are two factors that greatly influence the management of village funds, namely the competence of the village apparatus and internal control. The implementation of tasks in the village government must have competent apparatus resources and be able to account for the tasks given to them. Mitrani (2002) who said that competency is the nature of a person which itself is related to the implementation of a job effectively and successfully. Wida (2017), stated that at the accountability stage it was still not going well because the human resources of the implementing team in making administrative reports were still lacking, which then hampered the timeliness in submitting the SPJ. Kholmi (2016) found an obstacle in managing village funds in Kedungbetik village was the lack of understanding of village officials in implementing village funds. Nafidah (2017) research also found that human resource capabilities were limited, village assistance was not optimal and there was an unequal understanding between the village and the local government on some budgetary expenditure allocations for village activities. In contrast to Elni Allo Linggi (2016), it was found that the Lembang village officials in North Toraja had conducted accountability in accordance with the prescribed format, but the problem was the submission of financial reports to the wider community that had not been implemented.

The factor that influences the next accountability is the internal control system. The internal control system is an effort to prevent fraud from occurring which is the main element of this corruption act by increasing and building good and comprehensive internal control (Romantis, 2014). Internal control is a system / procedure that exists in an organization to maintain the process of operating activities in accordance with established policies in order to achieve the goals of the organization itself.

According to Government Regulation 60 of 2008 explained that the Internal Control System is an integral process in actions and activities carried out continuously by the leadership and all employees to provide adequate confidence in achieving organizational goals through effective and efficient activities, reliability of financial reporting, security of assets country, and compliance with laws and regulations. Krismiaji (2010) states that internal control is an organizational plan and methods used to protect or protect assets and produce accurate and reliable information. 
This study focused on three sub-districts, namely Anggeraja Subdistrict, Alla Subdistrict and Baraka Subdistrict, on the grounds that these areas were centers of superior agricultural and plantation land from Enrekang District such as shallots, salak and coffee. As in Sub-District Alla has the results of coffee plantations that are well known to foreign countries. These three subdistricts are also the trade centers of the plantation products. In accordance with Permendagri the Republic of Indonesia 114 of 2014 concerning Village Development Guidelines which explains that Village Funds are used to finance government administration, implementation of development, community development and community empowerment. Village Fund Allocation in Enrekang Regency in 2017 is Rp. 89,128,443,000 and 2018 amounting to Rp. 97.508.525,000 (www.djpk.depkeu.go.id). When viewed from the number of Village Funds in Enrekang Regency in 2017 and 2018, the question arises whether this huge amount of funding has been well-managed and has benefited the community.

According to the findings of the Enrekang District Inspectorate team, the financial management of village funds in Enrekang District is still constrained by the bookkeeping of transactions that are not maximal, the management resources that are still lacking are caused by the selection of village instruments based on political choice rather than their abilities and knowledge. Therefore, researchers prefer to research this program because if these funds are managed honestly and well, then the results of development are also clearly seen and vice versa.

\section{LITERATURE REVIEW}

\section{Stewardship Theory}

This theory describes a situation in which management is not motivated by individual goals but rather is aimed at their main outcome goals for the benefit of the organization. Stewardship theory explains that management can behave well for the benefit of many parties, so that there will be a strong relationship between organizational satisfaction and success. The success of the organization itself can be achieved by maximizing management and principal utilities.

This Stewardship theory can be applied to government accounting research, government accounting has been prepared to meet the information needs of the relationship between stewards and principals. Accounting as a driver of the operation of transactions moving towards an increasingly complex and followed by the growth of specialization in accounting and the development of public sector organizations. Contract relationships between stewards and principals on the basis of trust, act collectively in accordance with the goals of the organization.

Stewardship theory can have implications for describing the existence of village government as a reliable public sector organization, accommodating the aspirations of its people, providing good services, and being able to account for what is entrusted to them. So that organizational goals for the welfare of society can be achieved optimally. Good governance can be seen from whether performance accountability is good or not (Mahsun, 2010). The village government has carried out its duties in making financial liabilities in the form of accountable and transparent financial statements that are consistent with the characteristics of financial statements (relevant, reliable, understandable and comparable).

\section{Accountability of Village Funds}

The main principle underlying the management of village finance according to Mardiasmo (2002: 105) is the principle of transparency or openness which means that community members have the same rights and access to know the budget process because it concerns the aspirations and interests of the community, especially the fulfillment of village communities.

Village fund management is an inseparable part of village financial management in the Village Budget by Therefore, in financial management village funds must meet the management principles of deep fund allocation (Lapananda, 2016) as follows: a. All activities funded by village funds are planned, implemented and evaluated openly with the principles of, by and for the community b. All activities must be accounted for administratively, technically, and legally c. Village funds are carried out using the principles of frugality, direction and control. $d$. The types of activities to be funded through village funds are very open to improving community service facilities in the form of meeting basic needs, strengthening village institutions and other activities needed by village communities through village meetings Village funds must be recorded in the village income and expenditure budget.

To realize accountability must be supported by the existence of a good financial management and reporting system to be relevant and easily understood by stakeholders (Lestari, 2014). Financial statements become a very important thing to give to the trustee because through financial statements, the trustee can know the financial position of the organization can make certain decisions to support the continuity of an organization.

\section{Village Device Competence}

Widodo (2001) explains the competence of human resources is the ability of human resources to carry out the duties and responsibilities given to him with the provision of education, and experience that is quite adequate. Human resources are an important determining factor in every organization because as one of the elements of the strength of the competitiveness of the organization as well as the main determinant of the organization in improving its products or services to the community. Therefore, human resources must be competent by having high competence and performance. 
According to Marihot (2002), explained that human resources must be managed properly to improve the effectiveness and efficiency of the organization because it is one of the important factors in government. The ability of a person or individual, an organization (institution) or a system to carry out its functions or authority to achieve its objectives effectively and efficiently.

Village officials in this case act as human resources in village management must be able to have competencies supported by accounting education backgrounds, often attend education and training, have experience in finance. This is needed to implement the existing accounting system. Competent Human Resources (HR) will be able to understand the logic of accounting properly. The failure of the local government human resources in understanding and applying the logic of accounting will have an impact on the financial statements that have been made and report incompatibility with the standards set by the government.

\section{Internal Control System}

According to Government Regulation 60 of 2008, the internal control system is "An integral process in actions and activities carried out continuously by the leadership and all employees to provide adequate confidence in achieving organizational goals through effective and efficient activities, reliability of financial reporting, security state assets, and compliance with statutory regulations ". While the Government Internal Control System (SPIP) is an internal Control System that is carried out thoroughly in the central government and regional governments.

\section{RESEARCH METHOD}

This research is quantitative research, with research design hypothesis testing studies to test the influence between variables. According to Wahyudin (2015) the study of hypothesis testing aims to analyze, describe, and obtain empirical evidence of the pattern of relations between two or more variables. Theory is very needed in this research. Theory is used as a basis in submitting a hypothesis and for determining measurement criteria for the variables studied.

To see the relationship between financial management, village competency, internal control system and community participation in village financial accountability in the district government. Regents of Kab. Enrekang Causal research aims to test hypotheses and is a study that explains phenomena in the form of relationships between variables (Erlina, 2008). The test results will be used as the basis for drawing conclusions, whether supporting or rejecting the hypothesis developed from theoretical studies.

The location of the study was carried out in each village government work unit in the working area of the Enrekang District Government of South Sulawesi Province and focused on 3 (three) sub-districts that manage large village fund allocations, namely Anggaeraja District, Baraka District, and Alla District. The data used in this study are primary data using a questionnaire.

The population in this study were village officials involved in managing village finance at each village government. For respondents in each village there were 3 village financial management officials (village head, village secretary, treasurer) and 3 community leaders. Sampling determination technique uses purposive sampling nonprobability sampling technique that is sampling technique that is found or determined by the researcher by selecting the subject based on specific criteria determined by the researcher. Of the 3 sub-districts there are 29 villages, for respondents in each village there are village heads, village secretaries, treasurers, and community leaders as many as 2 people in each village so the number of samples in this study is 145 people. Questionnaires were distributed to 145 respondents who were directly related to managing village budget funds. Of the 145 copies of the questionnaire, which can fulfill the requirements and be analyzed in this study were 125 questionnaires.

The variables used in this study consisted of dependent variables and independent variables. The dependent variable (dependent variable) is the variable that is the target of the study. The dependent variable examined in this study is Village Financial Accountability. Independent variables (independent variables) are variables that affect the dependent variable, while the independent variables used in this study include: Village Device Competence (X1) and Internal Control System (X2).

The method of data analysis in this research is Multiple Regression Analysis. The research data was processed using Statistical Package for Social Science (SPSS) version 22. Multiple linear regression analysis intends to estimate the state of village financial accountability when it is associated with two or more independent variables, namely the competence of the village apparatus and the internal control system.

\section{RESULTS}

\section{Descriptive Data Analysis}

The results of descriptive statistical analysis aim to describe the distribution of the results of questionnaires regarding research variables, especially on all indicators. In this study descriptive statistics can be seen in the minimum, maximum, average, and standard deviation values.

Table 1. Descriptive statistics

\begin{tabular}{|l|r|r|r|r|r|}
\hline \multicolumn{1}{|c|}{ Variable } & \multicolumn{1}{|c|}{$\mathbf{N}$} & \multicolumn{1}{c|}{ Minimum } & \multicolumn{1}{c|}{ Maximum } & \multicolumn{1}{c|}{ Average } & $\begin{array}{l}\text { Deviation } \\
\text { Standard }\end{array}$ \\
\hline Village Device Competence (X1) & 125 & 2 & 5 & 4,40 & 0,55 \\
\hline Internal Control System (X2) & 125 & 2 & 5 & 4,34 & 0.48 \\
\hline Village Fund Accountability Management (Y) & 125 & 2 & 5 & 4,28 & 0,69 \\
\hline
\end{tabular}

Source: data processed 
The village competency variable (X1) has a minimum value of 2 and a maximum value of 5. This means that the respondent's smallest answer is Disagree (TS) and the respondent's biggest answer is Sangat Setuju (SS). The average value of the respondent's answer is 4.40 greater than the standard deviation value of 0.55 , indicating that the competency variable of the village device has a good mean value which is a good representation of the research data.

The internal control system variable (X2) has a minimum value of 2 and a maximum value of 5. This means that the respondent's smallest answer is Disagree (TS) and the respondent's biggest answer is Sangat Setuju (SS). The average value of the respondent's answer is 4.34 greater than the standard deviation value of 0.48 , indicating that the internal control system variable has a good mean value which is a good representation of the research data.

The accountability variable for village fund management (Y) has a minimum value of 2 and a maximum value of 5. This means that the respondent's smallest answer is Disagree (TS) and the respondent's biggest answer is Sangat Setuju (SS). The average value of the respondent's answer is 4.28 greater than the standard deviation value of 0.69 , indicating that the variable public participation has a good mean value is a good representation of the research data.

\section{Respondent's Answer Description}

The village competency variable (X2) is measured by seven questions. Distribution of frequency of respondents' answers to each indicator and variable.

Table 2 Description of Variables of Village Device Competence (X1)

\begin{tabular}{|c|c|c|c|c|c|c|c|c|}
\hline \multirow{2}{*}{ Variable } & \multirow{2}{*}{ Indicator } & \multicolumn{5}{|c|}{ Frequency of Answer Options } & \multirow{2}{*}{\multicolumn{2}{|c|}{ Average }} \\
\hline & & STS & TS & $\mathbf{N}$ & $\mathbf{S}$ & SS & & \\
\hline \multirow{7}{*}{$\mathrm{X} 1$} & $\mathrm{X} 11$ & 0 & 0 & 0 & 65 & 60 & 4,48 & \multirow{7}{*}{4,40} \\
\hline & $\mathrm{X} 12$ & 0 & 0 & 1 & 84 & 40 & 4,31 & \\
\hline & $\mathrm{X} 13$ & 0 & 0 & 0 & 53 & 72 & 4,58 & \\
\hline & $\mathrm{X} 14$ & 0 & 0 & 1 & 67 & 57 & 4,45 & \\
\hline & $\mathrm{X} 15$ & 0 & 0 & 0 & 69 & 56 & 4,45 & \\
\hline & $\mathrm{X} 16$ & 0 & 0 & 1 & 84 & 40 & 4,31 & \\
\hline & $\mathrm{X} 17$ & 0 & 11 & 2 & 57 & 55 & 4,25 & \\
\hline
\end{tabular}

\section{Source: data processed}

The village competency variable (X1) has a mean achievement of 4.40. This means that respondents consider the competence of the village apparatus to be very good in three villages that have a large budget allocation for village funds. The dominant indicator forming the competency variable of the village apparatus is the village budget management apparatus (X13) with a mean value of 4.58. This shows that most of the respondents consider that they can carry out their tasks in accordance with their time. On the contrary, the lowest indicator is the minimum human resources of accounting D3 (X17) with a mean value of 4.25 . This shows that the majority of respondents consider the financial resources human resources in managing village funds to be lacking in accounting. Overall, the village competency variable (X1) has an average value of 4.40 in the very high or very good category (average between 4.2-5.0). This shows that the competence variable of the village apparatus is perceived to be very high or very good by the respondents.

The internal control system variable (X2) is measured by ten questions. Distribution of frequency of respondents' answers to each indicator and variable.

Table 3 Description of Variables of Internal Control Systems (X2)

\begin{tabular}{|c|c|c|c|c|c|c|c|c|}
\hline \multirow{2}{*}{ Variable } & \multirow{2}{*}{ Indicator } & \multicolumn{5}{|c|}{ Frequency of Answer Options } & \multirow{2}{*}{\multicolumn{2}{|c|}{ Average }} \\
\hline & & STS & TS & $\mathbf{N}$ & $\mathbf{S}$ & SS & & \\
\hline \multirow{10}{*}{$\mathrm{X} 2$} & $\mathrm{X} 21$ & 0 & 0 & 1 & 84 & 40 & 4,31 & \multirow{10}{*}{4,34} \\
\hline & $\mathrm{X} 22$ & 0 & 0 & 0 & 87 & 38 & 4,30 & \\
\hline & $\mathrm{X} 23$ & 0 & 1 & 0 & 84 & 39 & 4,28 & \\
\hline & $\mathrm{X} 24$ & 0 & 0 & 0 & 80 & 45 & 4,36 & \\
\hline & $\mathrm{X} 25$ & 0 & 1 & 6 & 89 & 29 & 4,17 & \\
\hline & $\mathrm{X} 26$ & 0 & 0 & 0 & 42 & 83 & 4,66 & \\
\hline & $\mathrm{X} 27$ & 0 & 0 & 0 & 94 & 31 & 4,25 & \\
\hline & $\mathrm{X} 28$ & 0 & 0 & 0 & 103 & 22 & 4,18 & \\
\hline & $\mathrm{X} 29$ & 0 & 0 & 1 & 71 & 53 & 4,42 & \\
\hline & $\mathrm{X} 210$ & 0 & 0 & 0 & 69 & 56 & 4,45 & \\
\hline
\end{tabular}

\section{Source: data processed}

The internal control system variable (X2) has a mean achievement of 4.34. This means that respondents consider the internal control system to be very good in three villages that have a large budget allocation for village funds. The dominant indicator forming the internal control system variable is the expenditure of money with supporting evidence (X26) with a mean value of 4.66. This shows that the majority of respondents consider that financial accountability is accompanied by supporting evidence and in accordance with the applicable transaction conditions. Conversely, the lowest indicator is the support of the competent authority (X25) with a mean value of 4.17. This shows that most respondents consider that there is still a lack of authorization in each village fund management transaction and activity from the authorities. Overall the internal control system variable (X2) has an average value of 4.34 in the 
very high or very good category (average between 4.2-5.0). This shows that the internal control system variable is perceived to be very high or very good by the respondents.

The accountability variable for village fund management (Y) is measured by eight questions. Distribution of frequency of respondents' answers to each indicator and variable as shown in the following table.

Table 4 Description of the Variable Accountability for Village Fund Management (Y)

\begin{tabular}{|c|c|c|c|c|c|c|c|c|}
\hline \multirow{2}{*}{ Variable } & \multirow{2}{*}{ Indicator } & \multicolumn{5}{|c|}{ Frequency of Answer Options } & \multirow{2}{*}{\multicolumn{2}{|c|}{ Average }} \\
\hline & & STS & TS & $\mathbf{N}$ & $\mathbf{S}$ & SS & & \\
\hline \multirow{8}{*}{$\mathrm{Y}$} & Y11 & 0 & 28 & 0 & 42 & 55 & 3,99 & \multirow{8}{*}{4,28} \\
\hline & Y12 & 0 & 22 & 2 & 44 & 57 & 4,09 & \\
\hline & Y13 & 0 & 3 & 0 & 63 & 59 & 4,42 & \\
\hline & Y14 & 0 & 0 & 2 & 79 & 44 & 4,34 & \\
\hline & Y15 & 0 & 3 & 1 & 69 & 52 & 4,36 & \\
\hline & Y16 & 0 & 0 & 0 & 69 & 56 & 4,45 & \\
\hline & Y17 & 0 & 3 & 0 & 69 & 53 & 4,38 & \\
\hline & Y18 & 0 & 0 & 1 & 96 & 28 & 4,22 & \\
\hline
\end{tabular}

\section{Source: data processed}

The accountability variable for village fund management (Y) has a mean achievement of 4.28. This means that respondents consider community participation to be very good in three villages that have a large budget allocation for village funds. The dominant indicator forming the accountability variable for village fund management is the proportion of village government accountability in every public policy (Y16) with a mean value of 4.45. This shows that most respondents consider the explanation of village government proportionally every public policy will optimize the management of village funds. On the contrary, the lowest indicator is information openly, quickly and precisely to the public regarding the responsibility of the village government (Y11) with a mean value of 3.99. This shows that the majority of respondents consider the low level of information disclosure, the speed and accuracy of information about the responsibilities of the village government regarding the management of village budget funds. Overall, the village fund management accountability variable (Y) has an average value of 4.28 in the very high or very good category (average between 4.2-5.0). This indicates that the variable of village fund management accountability is perceived to be very high or very good by the respondents.

\section{Test Validity and Reliability}

Validity tests are used to measure the validity or validity of a questionnaire. A questionnaire is declared valid if the question or statement on the questionnaire is able to reveal something that will be measured on the questionnaire. Testing validity using Pearson Correlation. If the Pearson correlation value (r) is greater than 0.30 , it indicates that the item is valid and eligible to be included in the next stage. Conversely, if the Pearson correlation value (r) is smaller than 0.30 indicates the item is invalid. While the reliability test in this study was carried out statistically by calculating the amount of Cronbach's Alpha. Reliability test is used to measure a questionnaire used as an indicator of variables. If the alpha coefficient produced is $\geq 0.6$, then the indicator is said to be reliable or reliable.

Table 5 Recapitulation of Testing Validity and Reliability

\begin{tabular}{|c|c|c|c|c|c|c|}
\hline Variable & Indicator & Correlation & Conclusion & $\begin{array}{c}\text { Alpha } \\
\text { Coefficient } \\
\text { Standard } \\
\end{array}$ & $\begin{array}{l}\text { Cronbach's } \\
\text { Alpha }\end{array}$ & Conclusion \\
\hline \multirow{5}{*}{$\begin{array}{c}\text { Competence } \\
\text { Village Devices } \\
\text { (X1) }\end{array}$} & $\mathrm{X} 11$ & 0,647 & Valid & \multirow{5}{*}{0.6} & \multirow{5}{*}{0,635} & \multirow{5}{*}{ Reliable } \\
\hline & $\mathrm{X} 12$ & 0,481 & Valid & & & \\
\hline & $\mathrm{X} 14$ & 0,514 & Valid & & & \\
\hline & $\mathrm{X} 16$ & 0,760 & Valid & & & \\
\hline & $\mathrm{X} 17$ & 0,796 & Valid & & & \\
\hline \multirow{7}{*}{$\begin{array}{c}\text { System } \\
\text { Internal control } \\
(\mathrm{X} 2)\end{array}$} & $\mathrm{X} 22$ & 0,700 & Valid & \multirow{7}{*}{0.6} & \multirow{7}{*}{0,761} & \multirow{7}{*}{ Reliable } \\
\hline & $\mathrm{X} 23$ & 0,474 & Valid & & & \\
\hline & $\mathrm{X} 24$ & 0,751 & Valid & & & \\
\hline & $\mathrm{X} 25$ & 0,634 & Valid & & & \\
\hline & $\mathrm{X} 27$ & 0,588 & Valid & & & \\
\hline & $\mathrm{X} 28$ & 0,653 & Valid & & & \\
\hline & $\mathrm{X} 29$ & 0,740 & Valid & & & \\
\hline \multirow{7}{*}{$\begin{array}{l}\text { Accountability } \\
\text { Management } \\
\text { Village Fund } \\
\text { (Y) }\end{array}$} & Y11 & 0,755 & Valid & \multirow{7}{*}{0.6} & \multirow{7}{*}{0,820} & \multirow{7}{*}{ Reliable } \\
\hline & Y12 & 0,843 & Valid & & & \\
\hline & Y13 & 0,638 & Valid & & & \\
\hline & Y14 & 0,530 & Valid & & & \\
\hline & Y15 & 0,589 & Valid & & & \\
\hline & Y16 & 0,825 & Valid & & & \\
\hline & Y17 & 0,831 & Valid & & & \\
\hline
\end{tabular}

\section{Source: data processed}




\section{Hypothesis Testing Results}

To determine the feasibility of a research model is to look at the value of the coefficient of determination (R2). The coefficient of determination (R2) indicates the accuracy or goodness of fit of the model used. The greater the coefficient of determination (R2), which is reflected in the number of determination coefficients close to one (1), the better the model will be in explaining the effect of independent variables on the dependent variable. Conversely, the smaller the value (R2) or the value close to Zero (0), the better the model will be used.

Tabel 6 Goodness of Fit Model

\begin{tabular}{|c|c|c|c|l|}
\hline Equation Function & R-square & F-Statistics & Prob. & \multicolumn{1}{c|}{ Conclusion } \\
\hline $\mathrm{Y}$ & 0,294 & 12,363 & 0,000 & $\begin{array}{l}\text { Valid Model because the Prob (F-statistic) } \\
<\text { prob } \alpha=0.05 \text {, namely: } 0,000<0,05 . \\
\text { The model is quite well used because the } \\
\text { predictor variable (exogenous) in the model } \\
\text { contributes 29.4 percent in influencing the } \\
\text { response variable (endogenous), the remaining } \\
\text { 70.6 percent is influenced by other factors } \\
\text { outside the model. }\end{array}$ \\
\hline
\end{tabular}

\section{Source: data processed}

The results of multiple linear regression testing using SPSS version 22 software are shown in the following picture:

Table 7 Results of Multiple Linear Regression Analysis

\begin{tabular}{|c|c|c|r|r|c|}
\hline Variable Direct Relations & $\begin{array}{c}\text { Regression } \\
\text { Coefficient }\end{array}$ & $\begin{array}{c}\text { Standard } \\
\text { Error }\end{array}$ & t-Statistics & Prob. & Conclusion \\
\hline $\mathrm{X}_{1} \rightarrow \mathrm{Y}$ & 0,288 & 0,120 & 2,399 & $0,018^{* *}$ & Signifikan \\
\hline $\mathrm{X}_{2} \rightarrow \mathrm{Y}$ & 0,328 & 0,162 & 2,027 & $0,045^{* *}$ & Signifikan \\
\hline
\end{tabular}

Source: data processed

Table Description: $* * *)$ Significant at the 1 percent significance level

**) Significant at the 5 percent significance level

Based on the results of multiple linear regression analysis, the results of the analysis of the research model can be made as shown in Picture 1.

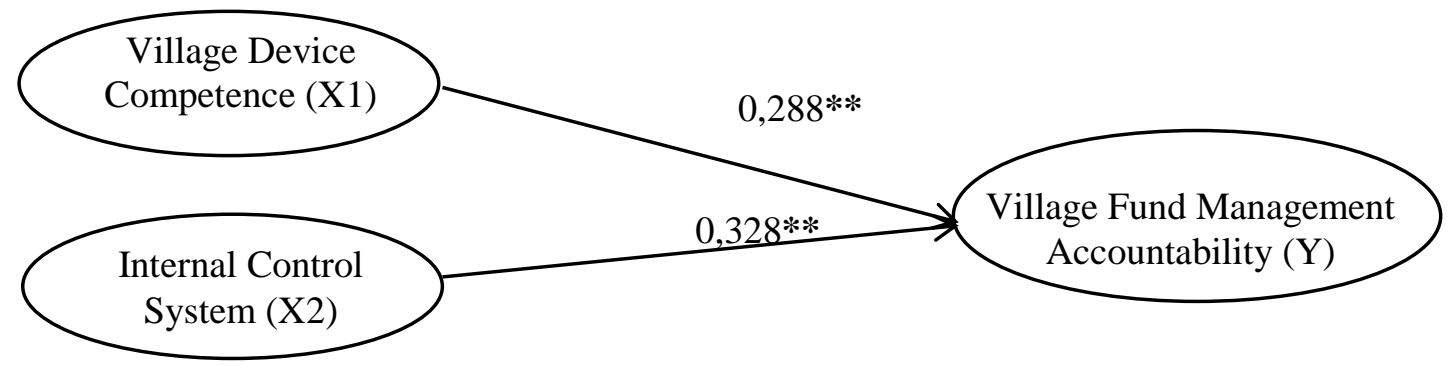

Picture 1

Results of Research Model Analysis

\section{Source: data processed}

Caption: ***) Significant at the 1 percent significance level

**) Significant at the 5 percent significance level

\section{DISCUSSION}

Village Device Competence Has a Positive and Significant Effect on Village Fund Management Accountability

The results of the regression analysis for the influence of village competency on the accountability of village fund management show a probability value of $0.018<0.05$. This value indicates that the competence of village officials has a significant effect on the accountability of village fund management. 
The coefficient value of the influence of village competency variables on the accountability of village fund management of 0.288 shows a positive direction. That is, the better the competence of the village apparatus, the better the accountability of village fund management. Thus, it was concluded that the second hypothesis which states that the competence of village officials has a positive and significant effect on the accountability of management of village funds is accepted.

The findings of this study illustrate that village leaders must master village financial management, are able to compile and implement village budget funds that are determined, education level influences task implementation, education possessed by desan apparatus especially in the field of village financial management and human resources in accounting will increase accountability of village fund management.

The findings of this study are consistent with Stewardship's theory (Davis et al, 1997: 24). Stewardship theory is one branch of psychology and sociology and is designed for researchers to test conditions in which executives as managers are motivated to do their best in the organization's main interests. In the theory of Stewardship, it is explained that executives as managers have a role in achieving organizational goals. The executive as manager can be elaborated into the scope of village fund management. Village government as executive / executor / manager / person in charge. Accountability theory according to Frinki and Klimoski (2004: 3) which states that accountability tends to revolve on two specific themes. The first theme concerns the context, namely who and what is involved in a particular situation. The second theme involves an understanding of evaluation and feedback activities in several forms.

These findings are consistent with the research conducted by Zirman et al. (2010) who found that the competence of local government officials had a positive effect on the accountability of performance of local government agencies. The results of this study are also in line with previous research by Subroto (2009). The results of his research suggest that the low competency of human resources in the village government apparatus is an inhibiting factor for the management of accountable Village Fund Allocation. The low competency of human resources as well as ineffective monitoring and evaluation results in discrepancies in the management of Village Fund Allocation. As a result, management accountability for the Village Fund Allocation does not reflect accountable management.

The results of Fajri's (2015), Irma (2015), and Makalalag (2017) studies show that village financial management (Village Fund Allocation and village funds) still has problems. As a result, village financial accountability has not fulfilled the principle of accountability. The constraints faced by the village government are due to the weak capacity of the village government itself. In implementing the management of village funds as a result of fiscal decentralization that is submitted by the central government to local governments and local governments to village governments, readiness is needed. One aspect that needs to be prepared is human resources (Ferina, 2016). Increasing human resources in the village can be carried out by the central government and regional governments. Among others, through socialization, monitoring, evaluation and supervision to support the realization of a prosperous and independent society (Dewi, 2016).

This indicates that village fund managers continue to be provided guidance from the sub-district government and district government on the management of village funds continuously so that they can master village financial management well even though most of their education level based on the results of the questionnaire is high school. Apparatus competency is a personal aspect of a worker that allows a person to achieve good performance. These personal aspects include the nature, motives, value systems, attitudes, knowledge and skills where competence will direct behavior, while behavior will produce performance. The competency of the apparatus is an important factor considering that competency is an internal factor and becomes an important factor.

\section{The Internal Control System Has Positive and Significant Effects on Accountability for Village Fund Management}

The results of the regression analysis for the influence of the internal control system on the accountability of village fund management show a probability value of $0.045<0.05$. This value indicates that the internal control system has a significant effect on the accountability of village fund management.

The coefficient value of the influence of the internal control system variable on the accountability of village fund management of 0.328 shows a positive direction. This means that the better the internal control system, the better the accountability of village fund management. Thus, it is concluded that the third hypothesis which states that the internal control system has a positive and significant effect on the accountability of management of village funds is accepted.

The findings of this study illustrate that the making and use of adequate documents and records, the proper separation of authority to conduct an activity or transaction, there are appropriate disciplinary actions for deviations from policies and procedures, or violations of rules of conduct, every transaction and activity has been supported by authorization from the authorities, control activities are regularly evaluated to ensure that the activities are appropriate and functioning properly, continuous channels of communication have been carried out openly and effectively with the community, partners and internal supervisors in providing significant input, and management officials Village budget funds review and evaluate findings that indicate weaknesses and need improvement will increase accountability of village fund management.

The findings of this study are consistent with Stewardship's theory which suggests that the interests of managers and principals are convergence, which means that both have the same goal towards one point, namely for the interests of the organization, where the interests of the organization are achieved. Management in private sector organizations has the same goal as regional heads in public sector organizations, namely to produce quality regional financial management information through improved human resources, 
utilization of information technology and effective internal control systems. Stewardship theory tends to consider risks that are in line with the internal control system that has an element of risk assessment by considering the risks that might be faced to produce good and accountable village fund management.

The findings of this study are consistent with the opinion of Aikins (2011) that government oversight increases financial accountability through evaluation and improvement of internal controls, risk management and governance processes. Organizing activities in a government starting from planning, implementing supervision, to accountability must be carried out in an orderly, controlled and efficient and effective manner. For this reason, a system is needed to provide adequate assurance that the implementation of activities in a government agency can achieve its objectives efficiently and effectively, report financial management reliably, secure assets and encourage compliance with laws and regulations, known as the Internal Control System (SPI). ) The Internal Control System in Government is an important factor, because the existence of a control system can affect the village government's internal decision making and can have implications for the accountability and transparency of the village government.

The findings of this study are consistent with the research conducted by Ramon (2014) which examined the effect of internal control on financial accountability in the Inspectorate of the City of West Sumatra with the results of the analysis showing the internal control system has a positive and significant effect on financial accountability. The findings are also in line with the research conducted by Widyatama et al. (2017), Wulansari and Pratiwi (2014) who found that the internal control system had a positive and significant effect on the accountability of village governments in managing village fund allocation.

\section{CONCLUSION}

Based on the results of the analysis and discussion that have been submitted previously related to the influence of the competence of the village apparatus and the internal control system on the accountability of village fund management, some conclusions can be drawn as follows:

1. Competence of village officials can increase accountability in managing village funds. This shows that the higher the competency of village officials in managing village funds has implications for the better accountability of village fund management. The better the village leader controls village financial management, is able to compile and implement the stipulated village budget, the level of education influences the implementation of tasks, education owned by the desan apparatus especially in the field of village financial management and human resources in accounting will increase the accountability of village fund management.

2. The internal control system can improve the accountability of village fund management. This shows that the better the internal control system in the village fund budget has implications for the better accountability of village fund management. The better the local government makes and uses adequate documents and records, the proper separation of authority to carry out an activity or transaction, there are appropriate disciplinary actions for deviations from policies and procedures, or violations of rules of conduct, every transaction and activity has been supported by authorization from the authorities, control activities are regularly evaluated to ensure that the activities are appropriate and functioning properly, continuous communication channels have been carried out openly and effectively with the community, partners and internal supervisors in providing significant input, and village fund budget management apparatus reviewing and evaluating findings that indicate weaknesses and need improvement will increase the accountability of village fund management.

\section{REFERENCES}

(1) Adisasmita, Rahardjo, 2006, Pembangunan Pedesaan dan Perkotaan. Yogyakarta, Graha Ilmu.

(2) Agrawal, Arun., dan Ribot, Jesse C. 1999. Accountability in Decentralization A Framework With South Asian and West African Cases. The Journal of Developing Areas. Vol.33, Page 473-502.

(3) Aikins, Stephen K. 2011. An Examination of Government Internal Audit's Role in Improving Financial Performance. Journal of Public Finance and Management, 11 (4): 306-337.

(4) Arifiyanto, Dwi Febri., dan Kurrohman, Taufik. 2017. Akuntabilitas Pengelolaan Alokasi Dana Desa di Kabupaten Jember. Jurnal Riset Akuntansi dan Keuangan. Vol.2, No.3, hal.481-493.

(5) Aziz, Nyimas Latifah Letty. 2016. Otonomi Desa dan Efektivitas Dana Desa. Jurnal Penelitian Politik. Vol.13, No.2 Hal. 193211.

(6) Davis, James H., Schoorman, F David., dan Donaldson, Lex. 1997. Toward a Stewardship Theory of Management. Academy of Management Review. Vol.22, No.1, Page 20-47.

(7) Devas, Nick., dan Grant, Ursula. 2003. Local Governent Decision Making-Citizen Participation and Local Accountability: Some Evidence From Kenya and Uganda. Public Administration and Developmen. Vol.23, Page 307-306.

(8) Dewi, Retno Astuti. 2016. Faktor-Faktor yang Berpengaruh terhadap Kinerja Keuangan Pemerintah Desa Pasca Penerapan Undang-Undang Nomor 6 Tahun 2014. Jurnal Akuntansi Aktual. Vol.3, No. 6 hal. 311-327.

(9) Ebrahim, Alnoor. 2003. Accountability In Practice: Mechanisms for NGO's. World Development. Vol.31, No.5, page 813829.

(10) Erlina. 2011. Metodologi Penelitian. Medan, USU Press. 
(11) Efendi, Marihot Tua. 2002. Manajemen Sumber Daya Manusia. Jakarta, Grasindo.

(12) Fajri, Rahmi. 2015. Akuntabilitas Pemerintah Desa pada Pengelolaan Alokasi Dana Desa (ADD) (Studi pada Kantor Desa Ketindan, Kecamatan Lawang, Kabupaten Malang). Jurnal Administrasi Publik (JAP). Vol.3, No.7, Hal.1099-1104.

(13) Ferina, Ika Sasti. 2016. Tinjauan Kesiapan Pemerintah Desa dalam Implementasi Peraturan Menteri Dalam Negeri Nomor 113 tentang Pengelolaan Keuangan Desa (Studi Kasus pada Pemerintah Desa di Kabupaten Ogan Hir). Jurnal Manajemen dan Bisnis Sriwijaya. Vol.14, No.3. Hal.321-336.

(14) Frinki, Dwight D., dan Klimoski, Richard J. 2004. Advancing Accountability Theory and Practice: Intorduction to The Human Resource Management Review Special Edition. Human Resource Management Review. Vol.14, Page 1-17.

(15) Ghozali, Imam. 2013. Aplikasi Analisis Multivatiate Dengan Program IBM SPSS 20. Edisi 6. Semarang: Badan Penerbit Universitas Diponegoro.

(16) Godrey,AH., AT., J., S. 2010. Accounting Theory $7^{\text {th }}$ Edition. Australia: John Willey.

(17) Halim Abdul. 2007, Akuntansi Sektor Publik : Akuntansi Keuangan Daerah. Jakarta, Salemba Empat.

(18) Hanifah, Suci Indah. 2015. Akuntabilitas dan Transparansi Pertangungjawaban Anggaran pendapatan belanja desa (APBDes). Jurnal Ilmu \& Riset Akuntansi Volume 4 Nomor 8.

(19) Haryanto, dkk. 2007. Akuntansi Sektor Publik. Edisi Pertama. Universitas Diponegoro.

(20) Indriasari, Desi dan Ertambang, Nahartyo. 2008. Pengaruh Kapasitas Sumber Daya Manusia, Pemanfaatan Teknologi, dan Pengendalian Intern Akuntansi Terhadap Nilai Informasi Pelaporan Keuangan Daerah: Studi Pada Pemerintaha Kota Palembang dan Kabupaten Organ Ilir. Simposium Nasional AkuntansiXI, Pontianak.

(21) Isbandi Rukminto Adi. (2007). Perencanaan Partisipatoris Berbasis Aset Komunitas: dari Pemikiran Menuju Penerapan. Depok: FISIP UI Press.

(22) Irma, Ade. 2015. Akuntabilitas pengelolaan alokasi dana desa (ADD) di Kecamatan Dolo Selatan Kabupaten Sigi. e - Journal Katalogis Volume 3 Nomor 1 Januari 2015 hal 121 - 137.

(23) Karimah, Faizatul. 2014. Pengelolaan Alokasi Dana Desa dalam Pemberdayaan Masyarakat (Studi pada Desa Deket Kulon Kecamatan Deket Kabupaten Lamongan. Jurnal Administrasi Publik (JAP). Vol. 2. No. 4. Hal.597-602.

(24) Kementerian Desa, Pembangunan Daerah Tertinggal, dan Transmigrasi. 2015. Indeks Desa Membangun 2015. Jakarta : Kementerian Desa, Pembangunan Daerah Tertinggal, dan Transmigrasi.

(25) Kementerian Keuangan 2016. Kebijakan Pengalokasian dan Penyaluran Dana Desa Tahun 2017. Disampaikan pada Workshop Penyusunan Rancangan Peraturan Kepala Daerah mengenai Tata Cara Perhitungan, Pembagian dan Penetapan Rincian Dana Desa TA 2017. Redtop Hotel and Convention Center. 21-24 November 2016.

(26) Kholmi, M. 2016. Akuntabilitas pengelolaan alokasi dana desa ( studi kasus di desa Kedungbetik Kecamatan Kesamben Kabupaten Jombang). Jurnal Ekonomika - Bisnis Volume 07 Nomor 02 Juli 2016 hal 143 - 152.

(27) Kim, Soojin., dan Schachter, Hindy Lauer. 2013. Citizen Participation in The Budget Process and Local Government Accountability:Case Studies of Organizational Learning from the United States and South Korea. Public Performance and Management Review. Vol.36, No.3, Page 456-471.

(28) Komang, Ayu. 2014. Membedah Akuntanbilitas Praktik Pengelolaan Keuangan Desa Pakraman Kubutambahan Kecamatan Kubutambahan Kabupaten Buleleng Provinsi Bali. Singaraja: e-Journal Ak Universitas Pendidikan Ganesha.

(29) Komang Sartika Dewi, et al. 2014. "Pengaruh sistem pengendalian intern pemerintah dan pengawasan keuangan daerah terhadap nilai informasi laporan keuangan Pemerintah pada Satuan Perangkat Daerah (SKPD)”. E-journal Bisma Universitas Penddikan Ganesha Jurusan Manajemen, Volume 2, Tahun 2014.

(30) Krismiaji. 2010. Sistem Informasi Akuntansi. Yogyakarta, UPP AMP YKPN.

(31) LAN dan BPKP. 2000. Akuntabilitas dan Good Governance. Jakarta, Lembaga Administrasi Negara.

(32) Lapananda, Yusran. 2016. Hukum Pengelolaan Keuangan Desa. Buku I. Jakarta, Penerbit Rmbooks.

(33) Lestari. 2014. Pembuatan Media Pembelajaran Huruf Dan Angka Pada Taman Kanak -Kanak Siswi Peni 1 Sragen. Jurnal IJNS (Indonesian Journal on Networking and Security). Volume 3 No 1 (Januari 2014) ISSN: 2302-5700. Jawa Tengah.

(34) Mada, Sarifuddin. 2017. Pengaruh kompetensi aparat pengelola dana desa, komitmen organisasi pemerintah desa, dan partisipasi masyarakat terhadap akuntabilitas pengelolaan dana desa di Kabupaten Gorontalo.Jurnal Riset Akuntansi dan Auditing "Goodwill”. Vol 8 No. 2.

(35) Mahmudi. 2010. Manajemen Keuangan Daerah. Yogyakarta: Erlangga.

(36) Makalalag, Astri Juainita. 2017. Akuntabilitas Pengelolaan Dana Desa di Kecamatan Kotamobagu Selatan Kota Kotamobagu. Jurnal Riset Akuntansi dan Auditing “Goodwill”. Vol. 8, No. 1. Hal.149-158.

(37) Mamelo, Gresly Yunius Rainal. 2016. Analisis Pelaksanaan dan Penatausahaan Dana Desa pada Desa-Desa dalam Wilayah Kecamatan Kotamobagu Timur Kota Kotamobagu. Jurnal Riset Akuntansi dan Auditing “Goodwill”. Vol. 7, No. 2. Hal.148159.

(38) Mardiasmo. 2002. Otonomi Daerah dan Manajemen Keuangan Daerah. Yogyakarta: Andi.

(39) -----on. Akuntansi Sektor Publik. Yogyakarta, Andi.

(40) Mitrani, Alain. 2002. Manajemen Sumber daya Manusia Berdasarkan Kompetensi.terjemahan. Jakarta. Intermedia.

(41) Mulyana, Budi. 2006. Pengaruh Penyajian Neraca Daerah dan Aksesibilitas Laporan Keuangan Terhadap Transparansi dan Akuntabilitas Pengelolaan Keuangan Daerah. Jurnal Akuntansi Pemerintah.

(42) Nafidah, Lina N. 2017. Akuntabilitas pengelolaan keuangan desa di Kabupaten Jombang. Akuntabilitas: Jurnal Ilmu Akuntansi Volume 10 (2) Oktober 2017 hal 273 - 288.

(43) Nasution, Saufi Iqbal. 2009. Pengaruh Penyajian Neraca SKPD dan Aksesibilitas Laporan Keuangan SKPD Terhadap Transparansi dan Akuntabilitas Pengelolaan Keuangan SKPD di Pemerintahan Provinsi Sumatera Utara. Skripsi. USU.

(44) Nordiawan, Dedi. 2006. Akuntansi Sektor Publik. Jakarta: Salemba Empat . 
(45) Peraturan Pemerintah Republik Indonesia Nomor 71 Tahun 2010 tentang Standar Akuntansi Pemerintahan

(46) Peraturan Menteri Dalam Negeri No. 113 Tahun 2014 Tentang Pengelolaan Keuangan Desa.

(47) Rahmayani, Meta Dewi. 2012. Governance dalam Pelaksanaan Program Dana Desa (studi kasus di Desa Kagokan Kecamatan Gatak Kabupaten Sukoharjo). Artikel Ilmiah Mahasiswa. Jurusan Akuntansi, Fakultas Ekonomi, Universitas Jember (UNEJ).

(48) Riyanto, Teguh. 2015. Akuntabilitas Finansial dalam Pengelolaan Alokasi Dana Desa (ADD) di Kantor Desa Perangat Selatan Kecamatan Marangkayu Kabupaten Kutai Kartanegara. eJournal Administrasi Negara. Vol. 3, No.1. Hal.119-130.

(49) Romantis, A.P dan Kurrohman.T. 2014. Akuntabilitas Pengelolaan Alokasi Dana Desa di Kecamatan Panarukan Kabupaten Situbondo Tahun 2014. Artikel Ilmiah Mahasiswa. Jurusan Akuntansi, Fakultas Ekonomi, Universitas Jember (UNEJ)

(50) Septianis, Ray. 2012. Partisipasi masyarakat dalam mengelola Alokasi dana desa (add) di desa Tegeswetan dan desa Jangkrikan Kecamatan Kepil Kabupaten Wonosobo. Jurnal vol.4 No. 3, thn. 2012, hal.179 -188.

(51) Setiana, Novindra Dwi. 2017. Pengaruh pemahaman dan peran perangkat desa terhadap akuntabilitas pengelolaan dana desa. Jurnal Urecoll 2407-9189

(52) Siregar, Liper. 2011 . Pengaruh akuntabilitas publik, transparansi publik dan pengawasan terhadap pengelolaan APBD dengan standar akuntansi pemerintahan sebagai variabel moderator pada Pemerintah Kota Pematangsiantar. Tesis Sekolah Pascasarjana Universitas Sumatera Utara, Medan

(53) Sihaloho, Meylina.D. 2014. Faktor-faktor yang mempengaruhi akuntabilitas keuangan pemerintah Povinsi Sumatera Utara. Thesis. Medan: Universitas Sumatera Utara.

(54) Sopanah dan Wahyudi. 2010. Pengaruh Akuntabilitas Publik, Partisipasi Masyarakat dan Transparansi Kebijakan Publik terhadap Hubungan antara Pengetahuan Anggaran dengan Pengawasan Keuangan Daerah (APBD). Jurnal Akuntansi. Universitas Widya Gama Malang dan Malang Corruption Watch (MCW).

(55) Subroto, A. 2009. Akuntabilitas pengelolaan alokasi dana desa (studi kasus pengelolaan alokasi dana desa di desa - desa dalam wilayah Kecamatan Tlogomulyo Kabupaten Temanggung tahun 2008). Dipublikasikan. Tesis. Program Studi Magister Sains Akuntansi. Universitas Diponegoro Semarang.

(56) Sugiyono. 2010. Metode Penelitian Kuantitatif Kualitatif \& RND. Bandung, Alfabeta.

(57) ------. 2012. Statistika Untuk Penelitian. Bandung, Penerbit Alfabeta.

(58) Undang-Undang Republik Indonesia Nomor 6 Tahun 2014 Tentang Desa.

(59) Undang - Undang Republik Indonesia Nomor 33 Tahun 2004 tentang Perimbangan Keuangan antara Pemerintah Pusat dan Pemerintahan Daerah.

(60) Undang - Undang Republik Indonesia Nomor 17 Tahun 2004 tentang Keuangan Negara.

(61) Utami, Kurnia dan Efrizal, Syofyan. 2013. Pengaruh pengetahuan dewan tentang anggaran terhadap pengawasan keuangan daerah dengan variabel pemoderasi partisipasi masyarakat dan transparansi kebijakan publik. Jurnal WRA, Vol.1, No.1.

(62) Wahyuddin. 2016. Implementasi kebijakan alokasi dana desa di desa Ako Kecamatan Pasangkayu Kabupaten Mamuju Utara . e Jurnal Katalogis, volume 4 Nomor 5, Mei 2016 ISSN:2302-2019 hal 141- 149.

(63) Waluyo. 2009. Manajemen publik (konsep, aplikasi, dan implementasinya dalam pelaksanaan otonomi daerah). Bandung, CV. Mandar Maju.

(64) Wida, Siti Ainul. 2017. Akuntabilitas dan desa di desa - desa Kecamatan Rogojampi Kabupaten Banyuwangi. e journal Ekonomi Bisinis dan Akuntansi, Volume IV (2), 2017 hal 148 - 152.

(65) Widyatama,Arif, Lola Novita, dan Diarespati. 2017. Pengaruh Kompetensi dan Sistem Pengendalian Internal Terhadap Akuntabilitas Pemerintah Desa dalam Mengelola Alokasi Dana Desa (ADD). Berkala Akuntansi dan Keuangan Indonesia, 2 (2017): 1-20.

(66) Widodo, 2001. Implementasi Kebijakan. Bandung, CV Pustaka Belajar.

(67) Wulansari dan Pratiwi, 2014. Pengaruh Sistem Pengendalian Internal Pemerintah dan Sistem Pelaporan Keuangan Terhadap Akuntabilitas Kinerja Instansi Pemerintah Daerah (Survey Pada Dinas Pemerintah Daerah Kota Bandung). Widyatama Repository, diakses 10 Nopember 2018.

(68) Zeyn, Elvira. 2011. Pengaruh Good Governance dan Standar Akuntansi Pemerintahan terhadap Akuntabilitas Keuangan dengan Komitmen Organisasi sebagai Pemoderasi. Jurnal Reviu Akuntansi dan Keuangan. Vol.1, No.1, Hal.21-37.

(69) Zirman, Edvan, dan Rozi. 2010. Pengaruh Kompetensi Aparatur Pemerintah Daerah, Penerapan Akuntabilitas Keuangan, Motivasi Kerja dan Ketaatan Pada Peraturan Perundangan terhadap Akuntabilitas Kinerja Instansi Pemerintah. Jurnal Ekonomi 18. 